\title{
Trademark in the Sudanese Laws
}

\author{
(Analytical Legal Study)
}

\author{
Prepared by: \\ Dr. Jouda Ibrahim Mohamed Alnour \\ Associated Professor \\ Faculty of Law -University of Gezira
}

March, 2021 


\begin{abstract}
:
Given the importance of the well-known trademark, it has enjoyed a special protection that differs from other trademarks, so the research aims to highlight the law's role in protecting marks, and to present the role of the civil judge in protecting marks. The research come up with many results such as follows: Despite the importance of the well-known trademark, the legislation stipulated in it did not define it, but rather left that within the framework of the mission of jurisprudence and the judiciary, The criteria by which the reputation of the mark is measured consists of two types: First: The objective criterion, which relates to the extent of the public's knowledge of the mark, the period of use of it, the period of publicity and advertisement thereof, the number of countries in which it is registered, and its value in the commercial markets as an exception to the principle of territoriality, which requires its protection to be registered in the territory of the country from which protection is sought, and from the principle of specialization that defines the scope of protection for goods and services similar to those distinguished by the well-known mark. The research recommend the followings: Branched and non-governmental intellectual organizations should be established in the state, The Sudanese legislator must address issues of deficiency in the inclusion of some commodities and products not included in the definition, and We would like the legislator to show us the limits of the mark's fame, i.e. whether the fame inside the country is sufficient to consider it a famous mark, or should this fame be on the international level.
\end{abstract}

Keywords: mark, trades, legislation, criteria, advertisements 
نظرًا لأهمية العلامة التجارية المشهورة، فقد تمتعت بحماية خاصة تختلف عن العلامات التجارية

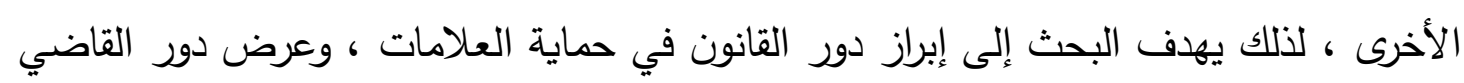

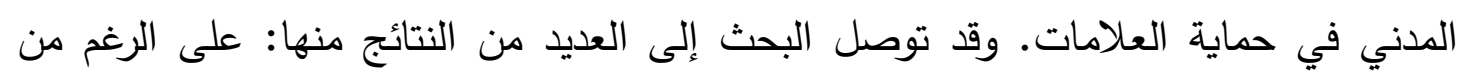

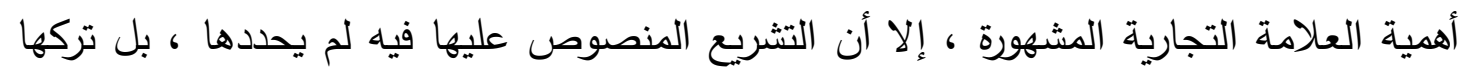
في إطار رسالة الفقه والقضاء. التي تقاس سمعة العلامة من نوعين: الأول: المعيار

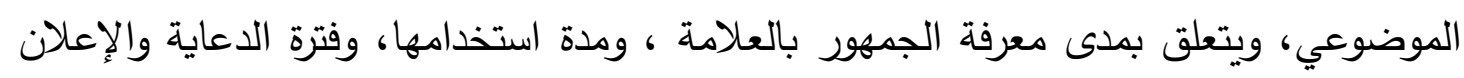

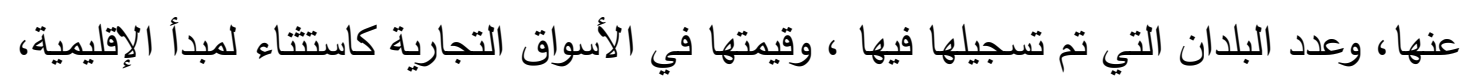
التي تتطلب أن يتم تسجيل حمايتها في أراضي الدولة المطلوب منها الحماية، ومن مبدأ

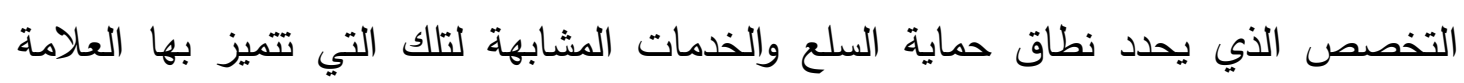
المشهورة. يوصي البحث بما يلي إنثاء منظمات فكرية متفرعة وغير حكومية في الولاية ، وعلى لهيل

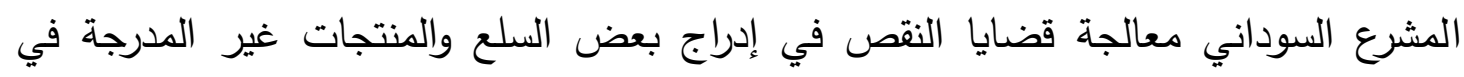

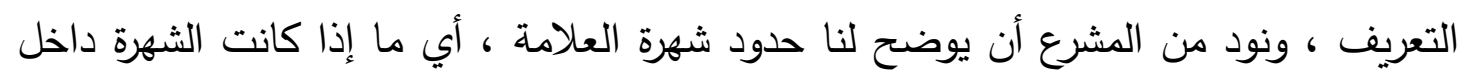
الدولة كافية لاعتبارها علامة مشهورة ، أم ينبغي أن تكون هذه الثهرة على الثئ المستوى الدولي. الكلمات المفتاحية: العلامة ، التجارية، التشريع، المعيار ، الدعاية والإعلان 


\section{Introduction:}

A trademark is everything that distinguishes a certain product, whether it is a good or service, from others, such as names that take a "distinct" shape, signatures, words, letters, numbers, drawings, symbols, bas-reliefs, or a group of colors that take a "distinct" shape, and others. The trademark is divided in terms of the public's knowledge of it into an ordinary brand and a famous mark, the latter which appeared as a result of the globalization of trade and the amazing development in means of communication and advertising. It plays a "distinguished" role in contemporary economic life. Distinguish the source of the good or service, and it is also a means of communication between the owner of the mark and the consumer of the goods. Today, people see that economic projects seek to promote their goods by using attractive means to the public represented by well-known and distinct signs in themselves in order to be able to attract and attract the largest possible number of consumers and make them dependent on the product through various advertising means such as radio, television, press, flyers and posters that are placed on the roads. The consumer often looks at the mark that distinguishes the commodity before deciding to buy it, as the mark replaces the examination and search for the quality of the product because the fame and reputation of the mark means the quality or the availability of the qualities that the consumer wants in the product. A trademark that is of poor manufacture. Given the importance of the well-known trademark, it has enjoyed a special protection that differs from other trademarks. Therefore, international agreements have multiplied to protect the well-known mark and guidelines and criteria have been set for it to identify it and distinguish it from the regular (not well-known) marks. . To be aware of all this, we will divide the research topic into two sections, the first to define the well-known trademark and to two requirements, one of which is to define the well-known trademark as a "language and convention", and the second is for the criteria for the reputation of the trademark. As for the second topic, we will devote it to the legal protection of the well-known trademark and 
to two requirements, the first for civil protection, and the second in which we will deal with the criminal protection of the well-known trademark.

Sudan is a member state of the Madrid Agreement for the International Registration of Marks (Stockholm Regulations 1967). Sudan follows the international classification of goods and services for the purpose of registering trademarks under the Nice Agreement, with the exception of trademarks covering alcoholic products where the aforementioned marks are not accepted for registration.

\section{Significance of the Study:}

esearch importance

Trademarks, like other intangible elements of the commercial store, aim to distinguish the merchant's products from others, enabling the customer to know the products by simply looking at their mark, which occurs in the same customer as the percentage of their quality, suitability, and satisfaction of his needs according to what they are accustomed to in the event that he previously bought them or read about their characteristics And their specifications. Due to the importance of trademarks in attracting customers and achieving profits, as well as marketing products, merchants continued to use them, and they deliberately increased the quality of their production to protect them from the competitions of similar projects, due to the good reputation that resulted from them, in order to ensure their superiority and marketing over their counterparts in the field of competition, so their financial value became great. Many of that are the most important elements for some shops. Accordingly, the protection of industrial property elements, especially trademarks, is a prerequisite for fair and fair competition regulation, and a fundamental factor in the economic performance of the market, in addition to that protection serves the interest of the consumer.

\section{Statement of the Problem:}


The legislations of the countries are concerned with regulating the legal protection of trademarks. It enacted legal provisions to put an end to the mockers' tampering with abuse of trade, by imposing penalties and conservative measures to protect consumers and business from offenders. Completing the registration of the trademark according to the form stipulated by the law results in international recognition of this mark, and this recognition lies in benefiting from the legal protection that the law provides for that registered mark, and this protection is evident in the law report a lawsuit for the trademark owner, requesting the judicial protection of his right to the mark And the possibility of prosecuting anyone who violates this right, and thus we wonder about the role of the law in protecting marks?

\section{Objectives of the Study:}

1. Highlight the law's role in protecting marks

2. To highlight the role of the civil judge in protecting marks 


\section{Theme One}

\section{Definition and Concept of trademark}

A trademark is a word, symbol, or phrase, used to identify a particular manufacturer or seller's products and distinguish them from the products of another. 15 U.S.C. $§ 1127$. For example, the trademark "Nike," along with the Nike "swoosh," identify the shoes made by Nike and distinguish them from shoes made by other companies (e.g. Reebok or Adidas). Similarly, the trademark "Coca-Cola" distinguishes the brown-colored soda water of one particular manufacturer from the brown-colored soda of another (e.g. Pepsi). When such marks are used to identify services (e.g. "Jiffy Lube") rather than products, they are called service marks, although they are generally treated just the same as trademarks.

Under some circumstances, trademark protection can extend beyond words, symbols, and phrases to include other aspects of a product, such as its color or its packaging. For example, the pink color of Owens-Corning fiberglass insulation or the unique shape of a Coca-Cola bottle might serve as identifying features. Such features fall generally under the term "trade dress," and may be protected if consumers associate that feature with a particular manufacturer rather than the product in general. However, such features will not be protected if they confer any sort of functional or competitive advantage. So, for example, a manufacturer cannot lock up the use of a particular unique bottle shape if that shape confers some sort of functional advantage (e.g. is easier to stack or easier to grip). Qualitex Co. v. Jacobson Products Co., Inc., 115 S. Ct. 1300 (1995).

Trademarks make it easier for consumers to quickly identify the source of a given good. Instead of reading the fine print on a can of cola, consumers can look for the Coca-Cola trademark. Instead of asking a store clerk who made a certain athletic shoe, consumers can look for particular identifying symbols, such as a swoosh or a unique pattern of stripes. By making goods easier to identify, trademarks also give manufacturers an incentive to invest in the 
quality of their goods. After all, if a consumer tries a can of Coca-Cola and finds the quality lacking, it will be easy for the consumer to avoid Coca-Cola in the future and instead buy another brand. Trademark law furthers these goals by regulating the proper use of trademarks.

\section{Definition of the Trademark in the Sudan Law:}

According to the article (3) of the Trademarks Law 1969 states that a trademark is defined as follows: "It means any visible sign related to or related to any goods and used or the use of which is proposed for the purpose of distinguishing the goods of a person from the goods or services of other persons, and unless their use is not permissible, the trademark may be from any distinctive mark, and this includes any word or A name, a pseudonym, a pictorial symbol, a trademark, an arbitrary or financial description, the title of a banner, a ticket, a signature, a letter, a number, a slogan, a parcel, a sign, a container, or any combination of the things mentioned above.

\section{Definition of service mark:}

Article (3) of the Trademarks Law 1969 states that a service mark is defined as follows: It means any visible sign used or proposed to be used to distinguish a person's services from that of others. It is one of the largest departments in the Intellectual Property Administration and has been working to receive applications since 1931, that is, for more than eighty years, and the number of applications has exceeded 50 thousand so far. The department is concerned with registering national trademarks and national service marks, based on applications submitted in accordance with the Trademarks Law of 1969 And its bylaw for the year 1969. It also registers international marks according to the Madrid system (agreement + protocol). 


\section{Theme Two}

\section{The Role Of The Patent And Trademark Office In Protecting The Public Interest: The Impact Of Consents}

\section{Introduction :}

As part of its statutory responsibilities, the Patent and Trademark Office ("PTO")5 may refuse registration of a mark under Section 2(d) of the Federal Trademark ("Lanham") Act upon a finding that such mark so resembles a previously registered or used mark as to be likely to cause confusion.6 One avenue open to an applicant confronted with such a refusal is to obtain the consent of the owner of the previously registered mark to the registration and use of the mark by the applicant. Judge Rich's opinions reflect the view that such consents should be respected. However, until the recent past, the PTO and the courts have been reluctant to accord such consents much weight, if any at all. For example, in In re Laskin Brothers, Inc., A case decided under the 1905 Trademark Act, the C.C.P.A. stated that "the Commissioner of Patents acts as the guardian of the public interests and the parties by their deeds or agreement cannot confer upon him the power to do that which he is prohibited from doing under the statute."8 During his tenure on the bench, Judge Rich played a leading role in effecting a reassessment of this view to reflect the realities of the marketplace. A review of his opinions on this issue reveals his deep understanding of the underpinnings of both U.S. trademark law9 and the role of the PTO

\section{Sources of law govern trademarks:}

Trademarks are governed by both state and federal law. Originally, state common law provided the main source of protection for trademarks. However, in the late 1800s, the U.S. Congress enacted the first federal trademark law. Since then, federal trademark law has consistently expanded, taking over much of the ground initially covered by state common law. The main federal statute is the Lanham Act, which was enacted in 1946 and most recently amended in 
1996. 15 U.S.C. $\S \S 1051$, et seq.. Today, federal law provides the main, and by and large the most extensive, source of trademark protection, although state common law actions are still available. Most of the discussion in this summary focuses on federal law.

\section{Ii. Functionality}

Few, if any, issues of trademark law have evoked as much controversy as the doctrine of functionality. At its core, the functionality doctrine serves the important public purpose of preventing trademark law from being used for anticompetitive purposes.39 While the purpose of the functionality doctrine may be simply explained, its application has proven difficult. In a series of decisions, Judge Rich sought to shed light on this issue. In two decisions issued on the same day-In re Deister Concentrator Co., Inc.40 and In re Shakespeare Co.41-Judge Rich explained the rationale for denying trademark protection to functional matter.

The principles set forth above were summarized by Judge Rich in Deister through reference to what he referred to in his opinion as trademark "truisms":

(1) Trademarks enable one to determine the existence of common source; but not everything that enables one to determine source is a trademark.

(2) A trademark distinguishes one man's goods from the goods of others; but not everything that enables goods to be so distinguished will be protected as a trademark.

(3) Some trademarks are words or configurations that are protected because they have acquired a "secondary meaning"; but not every word or configuration that has a de facto "secondary meaning" is protected as a trademark.

(4) A feature dictated solely by "functional" (utilitarian) considerations may not be protected as a trademark; but mere possession of a function (utility) is not sufficient reason to deny protection. 4 


\section{Iii. Trademark Subject Matter}

Writing for the C.C.P.A. in In re Cooper, Judge Rich held that the title of a single book cannot be a trademark, even if the mark consists of a coined term, in this case, TEENY-BIG. Judge Rich reasoned that however arbitrary, the title of a book nevertheless describes the book. "How else," he asked, "would you describe it—what else would you call it?"

\section{Iv. Generic/“So Highly Descriptive” Terms}

Judge Rich's decision in H. Marvin Ginn Corp. v. International Association of Fire Chiefs, Inc.77 provides the starting point for virtually all PTO decisions on the issue of genericness.78 Marvin Ginn involved a petition to cancel the registration for "Fire Chief," as used for a magazine directed to the field of firefighting. The Trademark Trial and Appeal Board found that "Fire Chief" designates a very particular and definable target audience for the magazine and, thus, is generic.79

\section{Concurrent Use}

One of the most problematic issues in trademark law is determining the respective rights of concurrent users of the same or similar marks in different parts of the country. Judge Rich explored this issue in his opinion for the court in Weiner King, Inc. v. The Wiener King Corp.

95 The facts are rather convoluted: Weiner King first used the mark WIENER KING in 1962 at restaurants located in Flemington, New Jersey, but did not apply for federal registration until May 1975.96 A North Carolina company, Weiner King Corp. ("WKNC"), began using the WIENER KING mark in 1970 in North Carolina in connection with restaurant services. At the time it adopted its mark, WKNC did not know of Weiner King and, in May 1972, WKNC obtained registrations for its marks. WKNC learned of Weiner King's use of the WEINER KING mark in July 1972 and subsequent thereto expanded its operations throughout the United States, including New Jersey. Weiner King 
petitioned to cancel WKNC's registrations and filed territorially unrestricted applications to register the mark WEINER KING. Weiner King then sued WKNC for trademark infringement. The district court granted Weiner King a preliminary injunction barring WKNC from using its mark within twenty miles of Weiner King's restaurants and also ordered the cancellation of WKNC's registrations.97 The Trademark Trial and Appeal Board, thereafter, granted Weiner King's petitions to cancel to the extent that WKNC's registrations were restricted to exclude Weiner King's trading area.98 The Board also recommended that Weiner King's applications be denied unless they were amended to reflect an area of right to use within a fifteen-mile radius of Flemington, New Jersey.99 Applying equitable and common law trademark principles, as well as the policy and substance of the Lanham Act, the C.C.P.A, per Judge Rich, affirmed the decision of the Trademark Trial and Appeal Board. Under the Tea Rose/Rectanus doctrine,100 Judge Rich noted, each party has the right to use its mark in its own initial area of use. The case was made more complicated, he pointed out, by the fact that, while WKNC was the junior user and an innocent adopter, it was nevertheless the first to register the mark and it expanded its use after learning of Weiner King's prior use. Weiner King contended that the fact that WKNC expanded even though it knew of Weiner King's prior user should bar it from being recognized as a concurrent user in any areas entered after notice. Judge Rich disagreed: It is said that nature abhors a vacuum. The same may be said of equity; it must operate in a factual environment. The TTAB had the task of balancing the equities between a prior user who remained content to operate a small, locally-oriented business with no apparent desire to expand, and who, until recently, declined to seek the benefits of Lanham Act registration, and a subsequent user, whose expressed purpose has been, from its inception, to expand into a nationwide franchising operation, and who has fulfilled its purpose, taking advantage of Lanham Act registration in the process.

\section{Vi. "Damage"}


Under Section 13 of the Lanham Act,103 an opposition may be filed by any person who believes he would be "damaged" by the registration of the mark on the principal register. In his decision in Otto Roth \& Co. v. Universal Foods Corp 104 Judge Rich explained that the concept of damage is tied to the grounds upon which the opposer asserts damage. He noted, for example, that in an opposition based on the allegation that the published mark is merely descriptive, any use by the opposer may be sufficient to preclude registration. Under such circumstances, the opposer is trying to prevent a claim of exclusive ownership of the mark, asserting a privilege that the opposer holds in common with all others to the free use of the language. However, Judge Rich continued, in an opposition based on Section 2(d) of the Lanham Act,105 the opposer is attempting to protect his individual rights. In this situation, Judge Rich declared, the oppose must prove he has proprietary rights in the term he relies upon to establish a likelihood of confusion.106

\section{Vii. Fraud}

Given the fact of continuing use, from which practically all of the user's substantive trademark rights derive, nothing is to be gained from and no public purpose is served by canceling the registration of a technically good trademark because of a minor technical defect in an affidavit."110

The court also distinguished fraud in trademark cases from fraud in patent cases. Judge Rich pointed out that every right of a patentee flows from rights granted by the Patent Office. However, trademark rights flow from use, not from registration: It is in the public interest to maintain registrations of technically good trademarks on the register so long as they are still in use. The register then reflects commercial reality. Assertions of "fraud" should be dealt with realistically, comprehending . . . that trademark rights, unlike patent rights continue notwithstanding

cancellation of those additional rights which the Patent Office is empowered by statute to grant.111 


\section{Viii. Likelihood Of Confusion}

For the most part, Judge Rich's jurisprudence on the issue of likelihood of confusion reflected prevailing law. Thus, for example, his decisions note that the issue of likelihood of confusion must be decided on the basis of the marks and goods and/or services set forth in the application and cited registration(s),115 that any doubt is resolved against the newcomer,116 that likelihood of confusion is not decided on the basis of a side-by-side comparison of the marks, 117 that absent evidence of use, third-party registrations are entitled to little weight in resolving the issue of likelihood of confusion,118 and that the fact that one mark may call another to mind does not by itself establish a likelihood of confusion.119 Many of his decisions relied heavily on the sophistication, or lack thereof, of the relevant purchasing public.120 Judge Rich also emphasized that what is important in a likelihood of confusion analysis "is not whether people will necessarily confuse the marks, but whether the marks will be likely to confuse people into believing that the goods they are purchasing emanate from the same source."121

The one issue in which Judge Rich's views fall outside the mainstream concerns the effect of a strong or famous mark on the question of likelihood of confusion. While the prevailing case law accords strong marks broad protection,122 Judge Rich took a contrary view. For example, in his dissent in Jiffy, Inc. v. Jordan Industries, Inc.,

\section{Ix. Descriptiveness}

Writing for the majority126 of the court in Minnesota Mining \& Manufacturing Co. v. Johnson \& Johnson, 127 Judge Rich determined that the mark SKINVISIBLE, as used on transparent adhesive tape through which the skin is visible, was not merely descriptive under Section 2(e)(1) of the statute. Judge Rich noted that SKINVISIBLE is highly suggestive in that it suggests that the skin is visible through the goods to which the mark is applied and also suggests the quality of invisibility in the tape. He pointed out, however, that a 
valid mark may be highly suggestive. Judge Rich further observed that SKINVISIBLE is not a dictionary term but, rather, a term coined by the applicant and that the evidence did not show that the term had become part of the language. Under such circumstances, he concluded, providing protection to SKINVISIBLE would not deprive competitors of the right to use the language in a normal manner. In another case, Remington Products, Inc. v. North American Philips Corp.128 


\section{Theme Three}

\section{Trademark in the Sudanese Laws}

The Sudanese legislator was interested in the trademark early, as we have found, since the year $1898 \mathrm{CE}$, the text of the Penal Code on provisions for the protection of trademarks, as the warning announcement that was published in the Official Gazette was a registration of the trademark and in this regard was the first warning announcement of the trademark in the form of a letter $\mathrm{N}$ for the merchandise of British water pipelines. In the year 1898AD and in the year 1925AD a new penal code was issued that included the same provisions for the protection of the trademark, then after that the issuance of the Trademarks Law for the year 1931 AD, then the Trademarks Law in 1969 AD which was issued in 1931 AD, then the Trademarks Law for the year 1969 AD that was issued on 3/29/3 1996 AD (Makki, 2009, 80)

It is believed that the definition of a trademark in Sudanese law has been marred by some shortcomings:

First: The Sudanese legislator sufficed by saying that the trademark is used to distinguish goods without stipulating what is meant by the goods, because the goods may be in its simple sense and it is just the goods in which he trades, and it may be in a broad sense, which is the goods resulting from any industrial, commercial, agricultural or land extracted work. (Dokki, 2000 p. 90)

The Khartoum Court of Appeal took the broad concept of merchandise and ruled that the main purpose of the trademark is to differentiate and distinguish between goods and goods that are manufactured or traded by every merchant, and the witness is the court's saying (the goods that he manufactures, and here any industrial business enters into the concept of goods according to Sudanese law.

Some Sudanese jurisprudence has reached the same conclusion by saying that the trademark is intended to distinguish different types of products, whether 
they are of an industrial, agricultural or extractive nature, and whether they are natural products or made by hand. (Abdeen, 2000, p.72)

Second: Originally, the definition of a trademark includes the product mark in addition to the service mark. However, the Sudanese legislator has taken a different position to this origin, and has made each of the trademarks and service mark an independent definition on its own. The problem is that this position leads to the assumption that there is a difference between The trademark and the service mark in Sudanese law.

In consolidation of this principle, the Court of Appeal in Khartoum ruled (Khader Business, Court of Appeal, Khartoum No. 2/1/2002 Commercial and $1 / 8 / 2003$, unpublished) that the trademark is divided into two parts, the first part is a trademark that distinguishes the products of a particular economic project, namely Signs are used and placed on the products and the second section

The second is service marks, which distinguish the services of an economic enterprise, and they are marks that are not placed on products but are placed on all tools and equipment used in the performance of a specific service, and that the mark is either associated with goods or services, and trademark laws regarding protection apply to service marks and trademarks alike. (Article 25 of the Sudanese Trademarks Law of 1969 AD,

It appears that, in response to the foregoing, the legislator stipulated in a subsequent article the application of the provisions of the Trademark Law to service marks, and in application to that, the owner of the service mark has the same legal protection for the trademark owner, and it is noticed that the comparative Arab laws have shown the origin that ends with the definition of the mark. The trademark includes the service mark. (Article 1 of the Saudi Marks System, for the year 1423 A.H.)

Third: It is noted that the legislator's definition of a trademark requires that the trademark be used or intended to be used, and that this condition is found to be 
misplaced because the use of the trademark or the mere intention to use it can be considered one of the conditions that must be met by the trademark in order for it to gain its character As a mark, some Sudanese jurisprudence has gone to the same conclusion that the use of the trademark or the intention to use is not considered a condition for the trademark to acquire the characteristic of a trademark for the registration of the trademark, but rather it is considered one of the reasons that the owner of the mark clings to in order to prove his eligibility to register it. (Abdullah, 2008 AD, p. 44)

A trademark is (any mark or group of signs that allows distinguishing the goods and services produced by a facility from those produced by other establishments is valid to be a trademark, and these marks, especially words that include names of people, letters, numbers, shapes, groups of colors and any combination of these marks are eligible for registration. As a trademark, member countries may make a mark for registration linked to discrimination acquired through use, and they may also require that the mark to be registered is perceptible by looking as an explanation for its registration.

dvantages of the Right to Mark:

1 - A relative, not an absolute right.

2- The right to a mark is temporary and not permanent.

3- The right to the mark has double protection

License to use the mark:

1. If the trademark is used after the approval of the registered owner by an intermediary of another natural or legal person, that use shall be considered a use by the registered owner himself, provided that the relations or arrangements existing between the registered owner and the user include a guarantee that the owner has effective supervision over the use of the trademark in relation to the nature of And the characteristics of the goods and provided that the trademark is not used in a way that may mislead the public opinion. 
2. Agreements between the relevant persons relating to the use of the registered trademark must be recorded upon request by either party within six months from the date of the agreement, and the registrant must issue a registration certificate under his signature in the prescribed form after paying the prescribed fee, provided that the registration is effective From the date of the application and the registration period does not exceed the period of registration of the mark itself, and any agreement not registered in the aforementioned manner shall have no effect and shall be considered null.

3. (a) The Minister may decide by order of him that his approval of the agreements related to the use of trademarks by the relevant persons is required, as well as the amendment and renewal of these agreements that include the payment of relative returns abroad, taking into account the needs of the country and its economic development (1)).

(B) The transfer of relative returns abroad is subject to the currency regulations in effect at the time of the transfer.

Trademark Terms: -

First: It must have a distinctive characteristic: -

A mark that does not contain a distinctive characteristic cannot be used as a trademark and must be rejected, and in order for the mark to be registrable and worthy of legal protection, it must be original in itself. Likewise, Egyptian and English law rejected this.

Second: To be new: -

Sudanese law, it is not permissible to register marks that are similar in a way that might reduce the public, and they do not lose the element of novelty unless they were previously used.

Third: To be legitimate: - 
National legislation is achieved by refusing to register a mark that contradicts morals or public order, or marks that are likely to mislead the public about the nature or quality of the commodity (1).

Illegal is what laws prevent its registration according to the Trademark Law. In Article 85, a mark may not be registered for the following: -

A - A mark that conflicts with morals and public order.

B - Signs similar to or similar to those of religious organizations or tribal sect.

C - Pictures or names of others unless their heirs agree to their use.Fourth: The language in which the sign is written: -

We find that most Arab laws stipulate that the trademark is written in the Arabic language, noting that this does not prevent the registration of a mark written in a foreign language other than the Arabic language, as the law stipulates in the use of the Arabic language that the trademark owned by Egyptians be written in the Arabic language and this does not preclude the registration of a mark written in a foreign language Besides the Arabic language (2).

As for the Sudanese law, the repealed trademark law does not require the mark to be written in a specific language or written in the Arabic language, and therefore it does not prevent the application to register a mark written in a foreign language in addition to the Arabic language.trademark registry, duties and powers of the registrant The first requirement: Trademark Registry: -

The law stipulates the establishment of a trademark registry that records all registered trademarks, the addresses of their owners, assignment notices, names and addresses of all users, registrars and assigns with any conditions, complications, renewals, relinquishment, cancellation, or similar issues related to trademarks. The record is kept in commercial registration offices (ownership The intellectual property) in Khartoum or other places designated by the minister with a matter published in the official newspapers. 
The second requirement: the duties of the registrar: -

Sudanese law specified the duties of the registrant as follows:

1- Article 9 of the Trademarks Law specifies the acceptance of trademark registration applications and their publication in the Official Gazette.

2- Acceptance of applications for objecting to trademark registration and adjudication.

3- Issuance of the mark registration certificate.

4- Registration of trademark assignment and transfer of ownership (1).

The third requirement: Registrar Powers: -

For the registrant in order to carry out the duties assigned to them by the following authorities: -

1- The report on all issues related to determining the section and the goods it contains.

2- Rejection of registering any trademark or accepting it without conditions.

3- Cancellation of any mark from the registrant unless it is renewed on the specified dates.

4- Requesting the court to cancel the registration of the mark if it is not worthy of registration in accordance with the law or was obtained through fraud.

5- Recommending to the Minister of Justice to issue rules, define forms, and take appropriate measures with the intention of:

A- Ensuring, organizing, publishing, selling or distributing copies of trademarks and other documents.

B- Organizing the registry process in relation to trademarks and matters included in the law under the supervision or control of the registrar.

The fourth topic: trademark registration procedures: - 
The first requirement: persons entitled to registration: -

The Sudanese Trademarks Law does not specify the persons who are entitled to apply for the registration of their marks, and there are several articles of the law that require that the application for registration of a mark be filed by a recognized agent if he is outside Sudan, and the only condition in submitting the application in Sudan is to indicate his nationality (1)

While other legislations, for example, the Saudi Trademark System, the applicant must be a citizen, if he is a foreigner, he must be a resident and authorized to conduct business in a business.

The second branch: registration requirements: -

In Article 9 of the law, the application for registering a trademark is submitted to the registrar in the prescribed form after paying the fees. The application includes the following:

A- Application for registration of the mark.

B- The full name and address of the applicant.

C- A legal power of attorney that bears the signature of the applicant. If the application is filed by an agent who is not a member of the Bar Association, the application is submitted to the Ornic S - No. 1 and includes the following data:

1- The section, which is one of the goods sections listed in the schedule.

2- Name, capacity, nationality and address in full of the person or the business. - A copy of the trademark attached to the box designated for it in the ORNIC.

4- If the trademark includes a word or words that change the English and Arabic languages, the registrant may have a printed translation of it, provided that it is made by a responsible person who means the position of contracts or chambers of commerce.

The third branch: acceptance of the application and rejection: - 
Upon receiving the trademark application, the registrant shall order an inspection between the registered trademarks and the suspended processes, whether the registrant has any similar mark because the similarity leads to fraud and refuses to register it if it is similar to another mark.

Whenever the application is before the mark, the mark is registered, and the registrant shall announce the application as soon as possible in the prescribed manner and indicate in the announcement all the conditions and changes based on them before the application.

The Commercial Law 1969 did not specify any period for deciding on the registration application.

The second requirement: Objecting to the registration, its renewal and its cancellation: -

The first branch: objection to registration:

The Trademarks Law allows any person who has an interest in this to object to the registration application within six months from the date of the announcement by accepting the application for registration if he is residing in Sudan and within eight months if he is outside Sudan (1).

In both cases, the objection must be made, if the objector has an interest in that, and the objection must be based on one of the reasons: -

A - The mark is not registrable according to the law.

B - that the applicant obtained the mark by fraud.

C - That he had no intention of using the mark when submitting the application and that the applicant had abandoned his mark permanently. The second branch: registration and renewal of the mark:

If no one objected to the trademark after its announcement in the official gazette during the specified period, or someone objected to the registration of 
the mark and the registrant decided to accept the registration, the trademark registration procedure continues and the registration certificate is issued by signing it in the prescribed copy.

The registration period is ten years from the date of registration, and he may at any time within six months renew the registration by submitting an application for this through the owner of the mark or an agent and paying the prescribed fees.

\section{Conditions for registration and renewal: -}

1- The renewal application shall be submitted by the owner of the mark or its representative.

2 - Not to make any change to the mark.

If the renewal application is not submitted within the specified period, the registrant shall send to the trademark owner at his address in the register a notification thereof on the EORNIC within a period of no less than two months and not more than three months before the last registration of the trademark expires (1).

And from some laws, the registration period differs from the Sudanese law, for example, the Egyptian one must be renewed within a year prior to its expiry date.The third branch: cancellation of the trademark: The trademark can be deleted as follows:

First: Failure to renew it: We mentioned previously the renewal period within 6 months prior to its expiration date. If the renewal request was not submitted, the registrant sends to the owner of the mark directly at his address in the register about that in the newspaper. The end of the last registration, and the registrar records the data for the cancellation of the mark from the registry and the reasons for it in the registry. He sends a notification of the cancellation to the owner of the mark on the Ornic and announces the cancellation in the newspaper. 
Second: Cancellation of the mark for non-use: (1).

Third: Cancellation of the mark obtained through fraud, Article 24 of the law, it is permissible for every interested party, even if the court is required to cancel the registration of any mark obtained through fraud

Fourth: Renunciation of the trademark: -

The owner of a trademark may waive the registration of the mark in whole or in part with respect to the goods that have been registered.

The Paris Agreement of 1883 AD did not specify conditions for the filing and registration of the mark, but rather left determining these conditions for each country through its internal legislation.

The Fourth Branch: Restrictions on Trademark Registration: -

Article 8 of the Trademarks Law of 1969 states that it is not permissible to register it:

1- Marks that contradict the system, or models that reflect a naturalism, intended in particular to deceive the commercial circles and public opinion.

2- Marks that imitate or imitate the official marks or the official seal of a state, unless approved by the competent authorities of that state.

3- Marks that simulate or imitate military medals or the media. 


\section{CONCLUSION AND RECOMMENDATIONS}

\section{Firstly: Findings:}

1. Despite the importance of the well-known trademark, the legislation stipulated in it did not define it, but rather left that within the framework of the mission of jurisprudence and the judiciary.

2. The criteria by which the reputation of the mark is measured consists of two types: First: The objective criterion, which relates to the extent of the public's knowledge of the mark, the period of use of it, the period of publicity and advertisement thereof, the number of countries in which it is registered, and its value in the commercial markets. Second: The personal criterion which is related to the extent of knowledge of the mark with the concerned public sector, and that the concerned audience differs according to what the good or service is directed towards.

3. Society is like specialists in a specific field, so the audience concerned here is this class of specialists.

4. "Legislation guarantees extensive protection for a well-known trademark, as an exception to the principle of territoriality, which requires its protection to be registered in the territory of the country from which protection is sought, and from the principle of specialization that defines the scope of protection for goods and services similar to those distinguished by the well-known mark.

5. The well-known meets the desire of the owners of these marks who have made efforts and expenditures in order to achieve the greatest possible fame for their trademarks in order to increase the sales of the products bearing this mark and thus increase the profits of the project.

6. The interest of the consumers of the products covered by the mark, as this protection guarantees them not to be confused or confused about the source of the products because they will have confidence that these products are from their original source and are not counterfeit. 
7. When submitting the trademark registration application, the mark is examined to ensure its ability to register, and in the event that the mark does not fulfill all the requirements mentioned in the law and order issued thereunder,

8. the trademark registrar rejects the application, and the applicant for registration has the right to object to the registrant's decision, requesting a reconsideration of it. The applicant for registration is based on the registrar's decision issued in the objection, and he may appeal it to the competent court.

9. The term of trademark protection in Sudan is 10 years from the date of filing and protection is renewable for equal periods, provided a request for renewal is submitted and the prescribed fees are paid. It is allowed to delay the renewal of the mark until the announcement of the cancellation of the mark is published in the

\section{Secondly: Recommendations}

1- Branched and non-governmental intellectual organizations should be established in the state

2- The Sudanese legislator must address issues of deficiency in the inclusion of some commodities and products not included in the definition

3- We would like the legislator to show us the limits of the mark's fame, i.e. whether the fame inside the country is sufficient to consider it a famous mark, or should this fame be on the international level.

4- also hope that our legislator will regulate special rules related to the protection of the well-known trademark in civil and criminal terms. 